\title{
EVALUATION OF DIETARY SUPPLEMENTATION OF PLEUROTUS OSTREATUS AND CALOCYBE INDICA IN SWISS MALE ALBINO MICE
}

\author{
JAWAHAR GANAPATHY ${ }^{1}$, EMILIN RENITTA ${ }^{2 *}$ \\ ${ }^{1}$ Department of Biotechnology, C. G. Bhakta Institute of Biotechnology, Uka Tarsadia University, Gopal Vidyanagar, Surat - 394 350, \\ Gujarat, India. ${ }^{2}$ Department of Food Processing and Technology, Karunya Institute of Technology and Sciences, Karunya \\ Nagar,Coimbatore - 641 114, Tamil Nadu, India. Email emilinrenitta@karunya.edu
}

Received: 14 July 2018, Revised and Accepted: 27 August 2018

ABSTRACT

Objective: The present study deals with dietary supplementation of Pleurotus ostreatus and Calocybe indica in Swiss male albino mice in comparison with casein control diet.

Methods: The Swiss albino male mice were divided into four groups. Group 1 served as normal, Group II served as control mice, and Groups III and IV mice were fed with food supplement $P$. ostreatus and $C$. indica for 28 days. After 28 days, the animals were euthanized by cervical dislocation, and liver samples were used to analyze the following parameters such as superoxide dismutase (SOD), catalase, glutathione peroxidase, reduced glutathione (GSH), Vitamin C, and Vitamin E.

Results: The results of the present study indicated that dietary supplementation of $P$. ostreatus and $C$. indica significantly (p<0.05) increased the antioxidants levels in experimental mice.

Conclusion: From the results, it was found that the mushrooms such as $P$. ostreatus and $C$. indica seem to be a promising source because of its antioxidant properties. Therefore, this medicinal mushroom could be used as a nutritional supplementation for human.

Keywords: Antioxidants, Dietary supplements, Pleurotus ostreatus, Calocybe indica.

(C) 2018 The Authors. Published by Innovare Academic Sciences Pvt Ltd. This is an open access article under the CC BY license (http://creativecommons. org/licenses/by/4. 0/) DOI: http://dx.doi.org/10.22159/ajpcr.2018.v11i10.28497

\section{INTRODUCTION}

Mushrooms are becoming a popular food in daily meal because of their nutritious and medicinal values. Edible mushrooms have been known for texture and flavor as well as medicinal and tonic attributes and utilized as a human food for centuries [1]. From the nutritional point of view, mushrooms contain appreciable amount of dietary fiber, particularly important for the regulation of physiological functions in human organism; furthermore, it contains a high amount of proteins and is excellent source of fibers, vitamins, and minerals [2]. These functional substances of mushrooms are able to lower cholesterolemia, modulate the immune system, and inhibit tumor growth [3].

Antioxidant is an important property by which living organisms can neutralize the toxic and cell-damaging molecules called free radicals which are generated during various metabolic reactions of the body [4]. Antioxidant in food plays an important role by reducing the risk for chronic diseases including cancer and heart disease. The fruiting bodies of mushrooms contain about $56.8 \%$ carbohydrate, $25.0 \%$ protein, and $12.5 \%$ ash on a dry weight basis [5]. The immune function throughout life can be influenced by nutrition. Possible ingredients for the development of functional foods that could contribute to optimal immune response include the antioxidant vitamins and trace elements (e.g., zinc, copper, manganese, magnesium, selenium potassium, B vitamins, and Vitamin D) [6]. Healthy nutrition and diet are gaining importance not only in the everyday life of human beings but also in the treatment of chronic diseases. Mushrooms are recognized worldwide as medicinal foods rich in nutrition by doctors. The Food and Drug Administration has officially designated mushrooms as "healthy foods" [7].

Oxidation is important to all living organisms for the production of energy to fuel biological processes. However, production of free radicals is involved in the cause of many diseases such as cancer, rheumatoid arthritis, and atherosclerosis as well as in degenerative processes associated with aging [8]. Even though there is free radical damage, all organisms can be protected by enzymes such as superoxide dismutase (SOD) and catalase (CAT), or compounds such as ascorbic acid, tocopherols, and glutathione (GSH). The presence of antioxidants in human diet acts as protective agents to reduce oxidative damage caused in the human body [9]. The present study was carried out to investigate the nutritional and antioxidant level of the diet prepared with Pleurotus ostreatus and Calocybe indica in Swiss male albino mice.

\section{MATERIALS AND METHODS}

\section{Experimental animals}

Swiss male albino mice (20-25 g, 8-10 weeks old) were purchased from the Agricultural University at Mannuthy (Thrissur, India). All mice were kept in a pathogen-free air-controlled room maintained at $24^{\circ} \mathrm{C}$ with a $50 \%$ relative humidity and 12 -h light and dark cycle. All mice had ad libitum access to a control diet (Hindustan Lever Ltd., Mumbai) and filtered water. All animal experiments were approved and performed according to the regulations of the Institutional Animal Ethics Committee, Government of India (IAEC Reg. No: IAECK/KU/BT/13/03).

\section{Grouping of mice}

After 1 week period of acclimatizing, the mice were randomly divided into four groups of six mice each. Group 1 served as normal, Group II served as control mice, and Groups III and IV mice were fed with food supplement $P$. ostreatus and $C$. indica for 28 days.

Group I=Normal diet

Group II=Control (casein) diet

Group III=Test diet - I (P. ostreatus)

Group IV=Test diet - II (C. indica)

*Mode of administration - oral route. 
Preparation of diets

The control (casein), P. ostreatus, and $C$. indica diets were prepared following the method of Vasconcelos [10]. The composition of control and test diets is given in Table 1; casein, mushroom powder, refined groundnut oil, vitamin mixture, salt mixture, dextrose, and corn starch were used as ingredients. Vitamin mixture and salt mixture were prepared by following the method of Mattison [11]. All the ingredients were mixed together with the addition of water and made into small balls $(30 \mathrm{~g})$ and stored at $-18^{\circ} \mathrm{C}$ in airtight containers. Feeding trials were carried out for 28 days. Feed and water were given ad libitum.

\section{Proximate composition analysis of the diets}

The protein content of each diet was determined by Lowry's method [12]. The total carbohydrate analysis was carried out by anthrone method [13]. The lipid content was estimated by Soxhlet extraction method of Association Official Analytical Chemists [14].

\section{Enzymatic and non-enzymatic antioxidant assay}

At the end of $28^{\text {th }}$ day, the mice were euthanized by cervical dislocation and the liver tissue recovered at necropsy was assessed for antioxidant activity such as SOD which was determined by following the method of Kakkar [15], CAT was performed by following the method of Sinha [16], glutathione peroxidase (GPx) was analyzed by following the method of Rotruck [17], GSH was estimated by following the method of Ellman [18], ascorbic acid (Vitamin C) was estimated by following the method of Omaye [19], and $\alpha$-tocopherol (Vitamin E) was estimated by following the method of Meydani [20]. Protein content was estimated using the Lowry method [12]. All liver samples (once prepared as homogenate) were used for the assays.

\section{Statistical analysis}

All the values were expressed as mean \pm standard deviation. The data were statistically analyzed using one-way Analysis of Variance (ANOVA), and the significant differences among the test groups were evaluated by Duncan's multiple range test. The results were considered as statistically significant at $\mathrm{p}<0.05$. All the statistical analyses were made using the Statistical Package for the Social Sciences 20.0 software package.

Table 1: Composition of control and test diets

\begin{tabular}{|c|c|c|c|}
\hline Ingredients & $\begin{array}{l}\text { Control } \\
\operatorname{diet}(\mathrm{g})\end{array}$ & $\begin{array}{l}\text { Test } \\
\text { diet - I (g) }\end{array}$ & $\begin{array}{l}\text { Test } \\
\text { diet - II (g) }\end{array}$ \\
\hline Casein & 12.6 & - & - \\
\hline Mushroom powder & - & 18.2 & 18.2 \\
\hline Refined groundnut oil & 7.0 & 7.0 & 7.0 \\
\hline Vitamin mixture & 1.0 & 1.0 & 1.0 \\
\hline Salt mixture & 2.0 & 2.0 & 2.0 \\
\hline Dextrose & 25.0 & 25.0 & 25.0 \\
\hline Corn starch & 52.4 & 46.8 & 46.8 \\
\hline \multicolumn{4}{|c|}{ Salt mixture (percentage) } \\
\hline $\mathrm{K}_{2} \mathrm{HPO}_{4}$ & & & 30 \\
\hline KCL & & & 9.4 \\
\hline $\mathrm{MgSO}_{4}$ & & & 14.8 \\
\hline $\mathrm{FeSO}_{4} \mathrm{H}_{2} \mathrm{O}$ & & & 1.4 \\
\hline $\mathrm{Ca}_{3}\left(\mathrm{PO}_{4}\right)_{2}$ & & & 27.4 \\
\hline $\mathrm{MnSO}_{4} \cdot 7 \mathrm{H}_{2} \mathrm{O}$ & & & 0.2 \\
\hline $\mathrm{CaCO}_{3}^{4}$ & & & 16.8 \\
\hline \multicolumn{4}{|c|}{ Composition of vitamin mixture } \\
\hline \multicolumn{3}{|l|}{ Vitamin A (as palmitate) } & $25000 \mathrm{IU}$ \\
\hline \multicolumn{3}{|l|}{ Vitamin $\mathrm{D}_{3}$} & $200 \mathrm{IU}$ \\
\hline \multicolumn{3}{|l|}{ Vitamin $\mathrm{B}_{12}^{3}$} & $1.0 \mathrm{mcg}$ \\
\hline \multicolumn{3}{|l|}{ Vitamin E acetate } & $5.0 \mathrm{mg}$ \\
\hline \multicolumn{3}{|c|}{ Vitamin $B_{2}$ (riboflavin) } & $1.5 \mathrm{mg}$ \\
\hline \multicolumn{3}{|c|}{ Vitamin $\mathrm{B}_{1}$ (thiamine monocitrate) } & $1.0 \mathrm{mg}$ \\
\hline \multicolumn{3}{|c|}{ Vitamin $\mathrm{B}_{6}$} & $1.0 \mathrm{mg}$ \\
\hline
\end{tabular}

\section{RESULTS}

The findings of the present investigation are based on the dietary supplementation of casein, P. ostreatus, and C. indica diets in Swiss male albino mice. Fig. 1 shows the biochemical composition of test diets. Dieting trials showed that the mice consumed the control and formulated diets in more quantities and the consumption of test diets was little lower than control diet. There was no non-acceptance by the mice for the diets containing $P$. ostreatus and $C$. indica and absolutely no unhealthy symptoms of deficiency disease or abnormal toxicities were observed in the mice throughout the experimental period.

The liver is the main organ of oxidative and detoxifying processes as well as free radical reactions; in many diseases, biomarkers of oxidative stress are elevated in the liver at an early stage. The present results showed a significant increase in SOD level for $P$. ostreatus and $C$. indica diet-fed groups (Fig. 2).

The effect of normal, control, $P$. ostreatus, and $C$. indica diets on liver CAT of Swiss male albino mice is shown in Fig. 3. In the present study, CAT significantly showed an increase in activity in mushroom-fed diet (I and II) than normal diet.

GPx is an enzyme that catalyzes the reduction of hydroxyl peroxides by GSH. Its main function is to reduce lipid hydroperoxides to their corresponding alcohols and to reduce free hydrogen peroxide $\left(\mathrm{H}_{2} \mathrm{O}_{2}\right)$ to water. In the present study, GSH significantly showed an increase in activity in mushroom-fed diets than normal diet (Fig. 4).

The activity of GSH reductase is used as an indicator for oxidative stress. The effect of normal, control, $P$. ostreatus, and $C$. indica diets on liverreduced GSH of Swiss male albino mice is shown in Fig. 5.

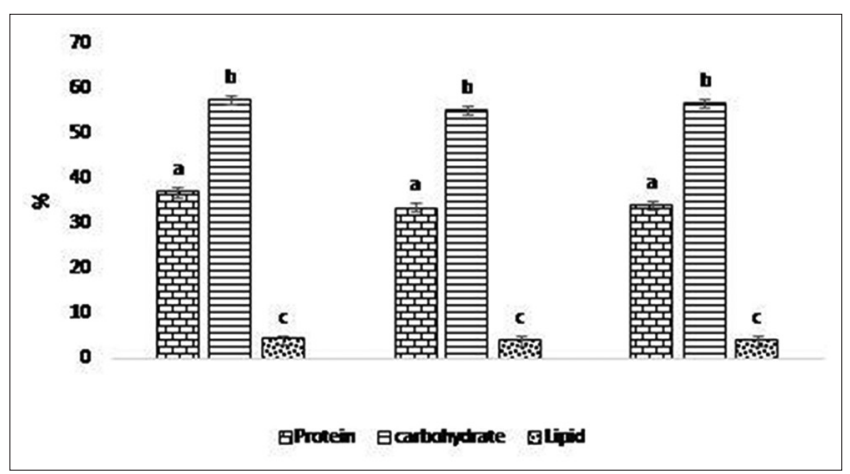

Fig. 1: Biochemical competition of diet. Values are \pm standard deviation for 6 mice each froup. Bars not sharing a common superscript letter ${ }^{(a, b, c)}$ differ significantly at $\mathbf{p}<0.05$ Duncan multiple range test

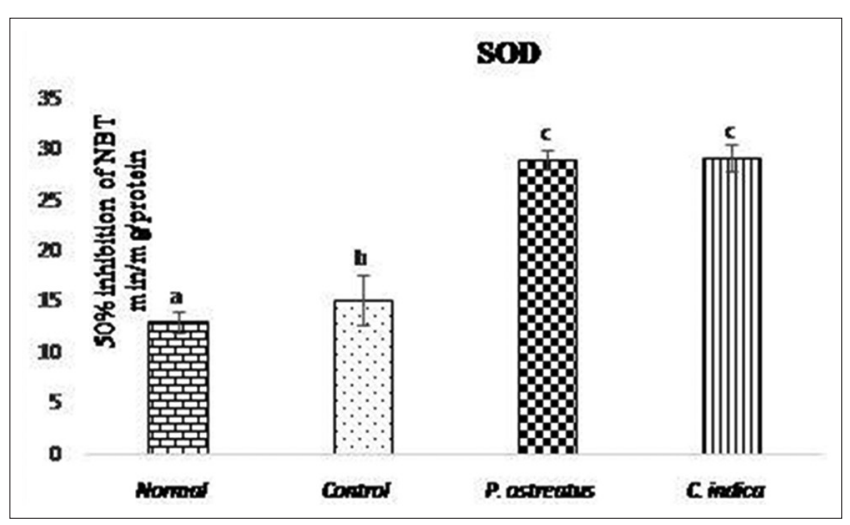

Fig. 2: Effect of normal, control, Pleurotus ostreatus and Calocybe indica diets on liver superoxide dismutase activity of Swiss male albino mice. Bars not sharing a common superscript letter ${ }^{(a, b, c)}$ differ significantly at $\mathbf{p}<0.05$ Duncan multiple range test 
Vitamin C is an anti-inflammatory and helps to prevent the inflammatory diseases, including arthritis, fibromyalgia, and chronic fatigue. A significant increase in Vitamin C level was noticed in P. ostreatus and C. indica (Fig. 6) diet-fed mice.

There was a significant increase in the Vitamin E levels in mushroom diet-fed mice (I and II), and it may due to the protection against oxidative stress involving in the tocopherol radical (Fig. 7).

\section{DISCUSSION}

Utilizing the promising functional foods has become an increasingly favored approach to the modulation of immune cell function [21]. Mushroom has a higher nutritional value such as proteins and vitamins similar to meat and eggs [22]. In the present era, the consumption of mushroom has been increased, and the consumption has been associated with the maintenance of health and in antioxidant defense in the prevention of many diseases. Mushroom diets are rich in total polyphenols, ascorbic acid, and vitamins which could be the main antioxidant compounds containing a wide variety of free radical scavenging molecules such as polyphenolic, triterpenoids, and steroids which have a strong antioxidant activity. It is reported that the total polyphenol was, naturally occurring antioxidant components, found higher in mushroom [23].

A significant increase could be due to the antioxidant enzyme which rapidly catalyzes the dismutation of superoxide anion and thus acts as the first-line antioxidant defense. There are many scientific research data that have provided a valid health supportive toward natural treatment for a variety of diseases $[24,25]$.

CAT has no electron donor requirement during detoxification of $\mathrm{H}_{2} \mathrm{O}_{2}$. CAT is a known antioxidant enzyme, and it has been involved in

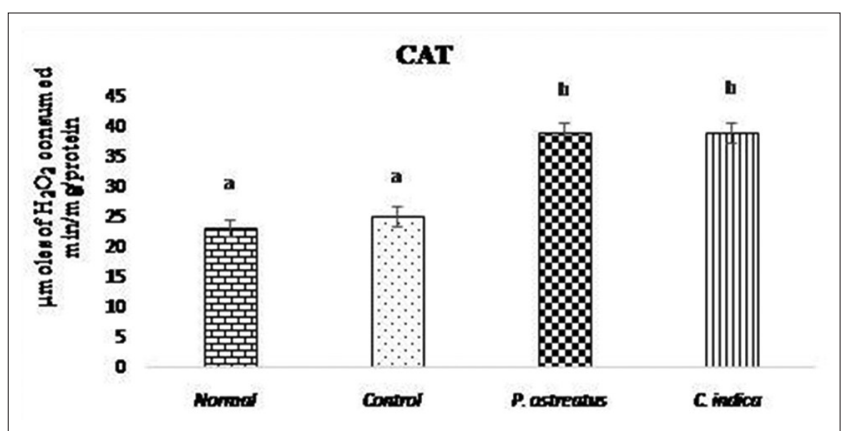

Fig. 3: Effect of normal, control, Pleurotus ostreatus and Calocybe indica diets on liver catalase activity of Swiss male albino mice. Bars not sharing a common superscript letter ${ }^{(\mathrm{a}, \mathrm{b}, \mathrm{c})}$ differ significantly at $p<0.05$ Duncan multiple range test

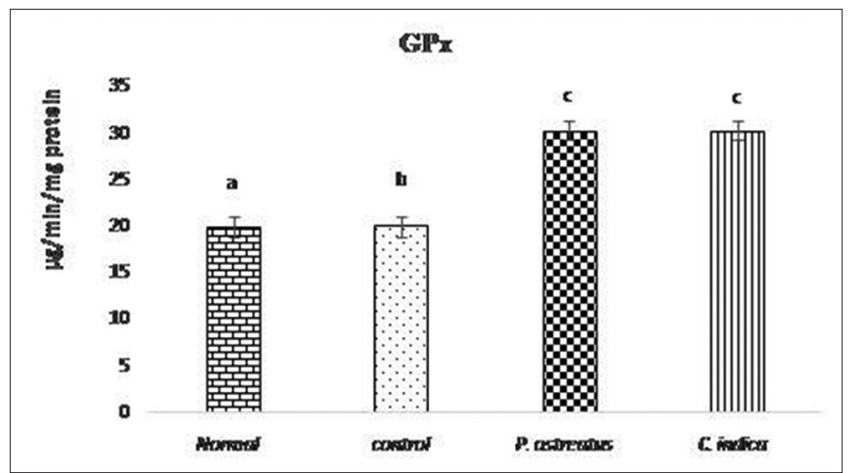

Fig. 4: Effect of normal, control, Pleurotus ostreatus and Calocybe indica glutathione peroxidase activity of Swiss male albino mice. Bars not sharing a common superscript letter ${ }^{(a, b, c)}$ differ significantly at $p<0.05$ Duncan multiple range test protection against $\mathrm{H}_{2} \mathrm{O}_{2}$; its localization is limited to the peroxisome [26]. $\mathrm{H}_{2} \mathrm{O}_{2}$ is a non-radical reactive oxygen species with weak oxidizing activity. It diffuses through cell membranes rapidly and interacts with Fe2+and possibly $\mathrm{Cu} 2+$ ions to form hydroxyl radicals and other free radicals [27]. The significant increase could be due to the antioxidant enzyme which is located in the cell's peroxisome, such as SOD naturally within the body. It converts $\mathrm{H}_{2} \mathrm{O}_{2}$ into water and oxygen, preventing the formation of carbon dioxide bubbles in the blood [28]. CAT also uses $\mathrm{H}_{2} \mathrm{O}_{2}$ to break down potentially harmful toxins in the body. CAT and SOD help to prevent free radical damage [29].

The significant increase could be due to the highly expressed scavenging and inactivating hydrogen and lipid peroxides, providing protection to the body against oxidative stress. GPx with other selenoproteins containing selenocysteine plays an important role in the GSH-dependent defense against peroxynitrite-mediated oxidations by serving as a peroxynitrite reductase [30].

GSH is a tripeptide with a gamma peptide linkage between the amine groups of cysteine and the carboxyl group of the glutamate side chain. It is an antioxidant, preventing damage to the important cellular components caused by reactive oxygen species such as free radicals and peroxides [31]. In the present study, the enhancement of GSH in $P$. ostreatus and $C$. indica mushroom diet-fed mice could be due to the tissue-specific efficiency of cysteine metabolism [32]

Vitamin C is also called as ascorbic acid, one of the important antioxidant acids, to maintain collagen in the skin, repair damaged tissue, promote healthy teeth and bones, and boost the immune system [33]. Vitamin C helps the body to absorb iron, which is also useful in treating iron deficiency and anemia [34]. Increased Vitamin C activity may due to the increase of GSH level because Vitamin C and GSH are synergistic antioxidants [35].

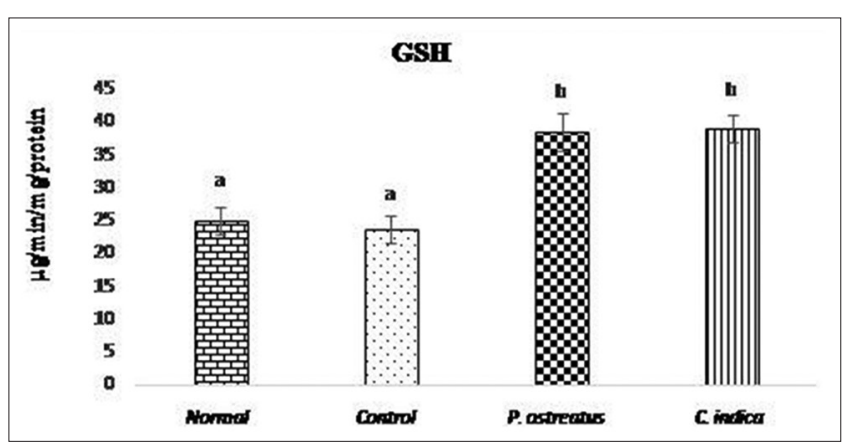

Fig. 5: Effect of normal, control, Pleurotus ostreatus and Calocybe indica diets on liver glutathione activity of Swiss male albino mice. Bars not sharing a common superscript letter ${ }^{(\mathrm{a}, \mathrm{b}, \mathrm{c})}$ differ significantly at $p<0.05$ Duncan multiple range test

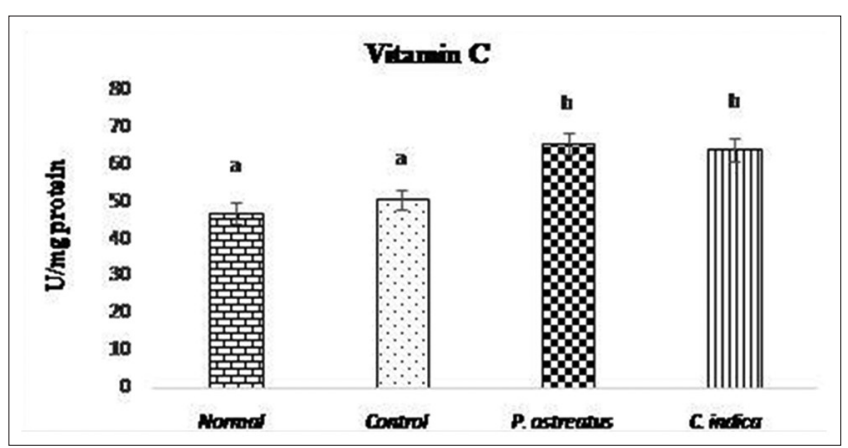

Fig. 6: Effect of normal, control, Pleurotus ostreatus and Calocybe indica diets on liver Vitamin $\mathrm{C}$ activity of Swiss male albino mice. Bars not sharing a common superscript letter ${ }^{(a, b, c)}$ differ significantly at $\mathrm{p}<0.05$ Duncan multiple range test 


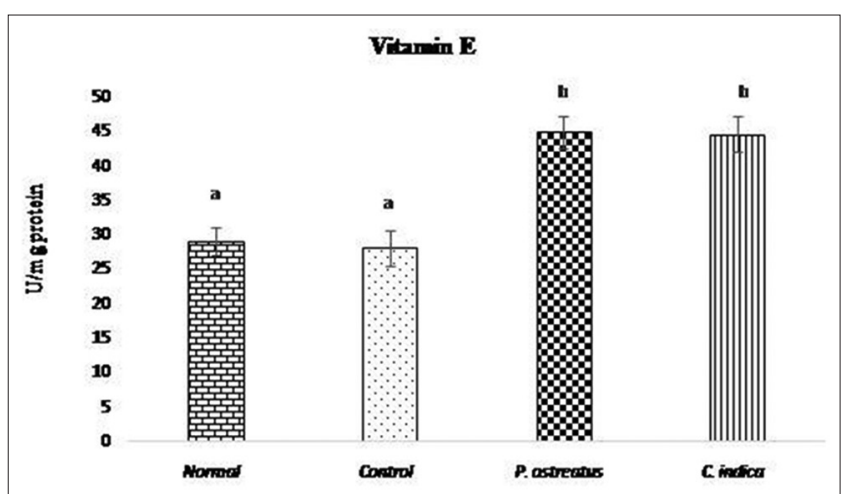

Fig. 7: Effect of normal, control, Pleurotus ostreatus and Calocybe indica diets on liver Vitamin $\mathrm{E}$ activity of Swiss male albino mice. Bars not sharing a common superscript letter ${ }^{(a, b, c)}$ differ significantly at $\mathbf{p}<0.05$ Duncan multiple range test

Vitamin E also protects the body from oxidation and normal aging process; the damage induced by diabetes and neutralizes the free radicals; when enough Vitamins $E$ is present in the body, the unstable free radicals get their electrons from the Vitamin E molecules and leave the healthy molecules alone, thus causing less damage to tissues [36]. Decreased activity in respect of casein diet may due to the lipid soluble chain-breaking antioxidants in the biological system protecting cell membrane from peroxidative damage [20].

\section{CONCLUSION}

Mushrooms are an excellent food that can be used in a well-balanced diet containing all essential nutrients which are necessary for therapeutic benefits, easy way to escalate overall immunity, for their functional compounds, and low-fat content provides valuable nutrients to the human. The results of the present study demonstrated that the dietary supplementation with $P$. ostreatus and $C$. indica mushrooms enhances the nutritional value of the diet and antioxidants levels. $P$. ostreatus and $C$. indica diet consumption may increase innate immunity against many diseases. A regular intake of mushrooms can maintain our body in good physical condition, fine fettle, de-stress, and enhance the immune responses of the human body, thereby increasing resistance to disease and, in some cases, regression of a disease state. Nutritional and therapeutic benefits revealed that the $P$. ostreatus and $C$. indica are suitable for making nutraceuticals and would help to decrease the malnourishment suffered by millions across the world.

\section{AUTHORS' CONTRIBUTIONS}

Authors have contributed equally.

\section{CONFLICTS OF INTEREST}

We (authors) have no conflicts of interest.

\section{REFERENCES}

1. Isabel CF, Ferreira PB, Miguel VB, Lillian B. Free-radical scavenging capacity and reducing power of wild edible mushrooms from Northeast Portugal: Individual cap and stipe activity. Food Chem 2007;100:1511-6.

2. Barros L, Baptista P, Correia D, Casal S, Oliveira B, Ferreira IC. Fatty acid and sugar compositions and nutritional value of five wild edible mushrooms from Northeast Portugal. Food Chem 2007;105:140-5.

3. Zhang $\mathrm{M}, \mathrm{Cu}$ IS, Cheung P, Wang Q. Antitumor polysaccharides from mushrooms: A review on their isolation process, structural characteristics and activity. Trends Food Sci Technol 2007;18:4-19.

4. Swagiary A, Nath P, Basumatary B, Brahma D. Phytochemical, antioxidant, and trace element analysis of anthelmintic plants of NorthEast India. Int J Pharm Pharm Sci 2017;9:228-32.

5. Ouzouni PK, Koller WD, Badeka AV, Riganakos KA. Volatile compounds from the fruiting bodies of three Hygrophorus mushrooms species from Northern Greece. Int J Food Sci 2009;44:854-9.

6. Sullivan R, Smith J, Rowan N. Medicinal mushrooms and cancer therapy: Translating a traditional practice into Western medicine. Perspect Biol Med 2006;49:159-70.

7. Babu D, Rao G. Antioxidant properties and electrochemical behavior of cultivated commercial Indian edible mushrooms. J Food Sci Technol 2013;50:301-8.

8. Thekkuttuparambil A, Ajithkainoor K, Janardhanan KK. Indian medicinal mushrooms as source of antioxidant and antitumor agents. J Clin Biochem Nutr 2007;40:157-62.

9. Lillian B, Soraia F, Paula B, Cristina F, Miguel V, Isabel CF. Antioxidant activity of Agaricus sp. mushrooms by chemical, biochemical and electrochemical assays. Food Chem 2008;111:61-6.

10. Vasconcelos I, Maia A, Siebra E, Oliveira J, Carvalho A, Melo V, et al. Nutritional study of two Brazilian soybean (Glycine max) cultivars differing in the contents of anti-nutritional and toxic proteins. J Nutr Biochem 2001;12:55-62.

11. Mattison JA, Roth GS, Lane MA, Ingram DK. Dietary restriction in aging non-human primates Interdiscip Top Gerontol 2007;35:137-58.

12. Lowry OH, Rosebrough NJ, Farr AL, Randall RJ. Protein measurement with the folin phenol reagent. J Biol Chem 1951;193:265-75.

13. Sadasivam S, Manickam A. Biochemical Methods. $2^{\text {nd }}$ ed. New Delhi: New Age International; 2002.

14. Association Official Analytical Chemists. Official Methods of Analysis of AOAC International. Gaithersburg: AOAC International; 2005.

15. Kakkar P, Das B, Viswanathan PN. A modified spectrophotometric assay of superoxide dismutase. Indian J Biochem Biophys 1984;21:130-2.

16. Sinha KA. Colorimetric assay of catalase. Anal Biochem 1972;47:389-94.

17. Rotruck JT, Pope AL, Ganther HE, Swanson AB, Hafeman DG, Hosekstra WG. Selenium: Biochemical role as a component of glutathione peroxidase. Science 1973;179:588-90.

18. Ellman GL. Tissue sulfhydryl groups. Arch Biochem Biophys $1959 ; 82: 70-7$

19. Omaye ST, Turbull TD, Sauberlich HC. Selected Method for the Determination of Ascorbic Acid in Animal Cells, Tissues and Fluids. New York: Methods Enzymol Academic Press; 1979.

20. Meydani M. Vitamin E and prevention of heart disease in high risk patients. Nutr Rev 2000;58:278-81.

21. Dayong W, Munkyong P, Zhuyan R, Donald S, Meydani NS. Dietary supplementation with white button mushroom enhances natural killer cell activity in C57BL/6 mice. J Nutr 2007;137:1472-7.

22. Selvi P, Uma DP, Suja S, Murgan S, Chinnaswamy P. Comparision of non enzymic antioxidant status of fresh and dried form of Pleurotus florida and Calocybe indica. Pak J Nutr 2007;6:468-71.

23. Ali K, Ilkay K, Huseyin G, Keles K. Antioxidant properties of wild edible mushrooms. J Food Process Technol 2011;3:2-6.

24. Lull C, Wichers H, Savelkoul H. Anti inflammatory and immune modulating properties of fungal metabolites. Med Inflamm 2005;9:63-80

25. Pacher P, Beckman J, Liaudet L. Nitric oxide and Peroxynitrite in health and disease. Physiol Rev 2007:87:315-424

26. Jayakumar T, Ramesh E, Geraldine P. Antioxidant activity of the oyster mushroom (Pleurotus ostreatus) on $\mathrm{CCl}(4)$-induced liver injury in rats. Food Chem Toxicol 2006;44:1989-96.

27. Shamsi TN, Parveen R, Sajida A, Ahamed A, Fatima S. Assessing the therapeutic role of joshanda: Phytochemical, antioxidant, anti-inflammatory and antimicrobial activities. Int J Pharm Pharm Sci 2018;10:122-8.

28. Kovacic P, Pozos RS, Somanathan R, Shangari N, Brien PJ. Mechanism of mitochondrial un couplers, inhibitors, and toxins: Focus on electron transfer, free radicals, and structure-activity relationships. Curr Med Chem 2005;12:2601-23.

29. Lee HY, Eum WS, Kim DW, Lee BR, Yoon CS, Jang SH, et al. Isolation and identification of an antioxidant enzyme catalase stimulatory compound from Garnoderma lucidum. J Biochem Mol Biol 2003;36:450-5.

30. Kern JC, Kehrer JP. Free radicals and apoptosis: Relationships with glutathione, thioredoxin and the BCL family of Proteins. J Biosci 2005;10:1727-38.

31. Pompella A, Visviki SA, Paolicchi A, De T, Casini AF. The changing faces of glutathione a cellular protagonist. Biochem Pharm 2003;66:1499-503.

32. Yang B, Hill CE. Nifedipine modulation of biliary GSH and GSSG/ conjugate efflux in normal and regenerating rat liver. Arch Gastrointest Liver Physiol 2001;281:85-94.

33. Jacob RA. Passive smoking induces oxidant damage preventable by Vitamin C. Nutr Rev 2000;58:239-41. 
34. Kojo S. Vitamin C: Basic metabolism and its function as an index of oxidative stress. Curr Med Chem 2004;11:1041-64.

35. Inga K, Maria M, Miroslawa S, Anna G. Effect of storage on the content of polyphenols Vitamin $\mathrm{C}$ and the antioxidant activity of orange juices.
J Food Compos Anal 2007;20:313-22.

36. Jawad A, Muhammad AA, Waqas A, Chaudhry MA, Jamil S. Effect of different substrate supplements on oyster mushroom (Pleurotus spp.) Production. Food Sci Technol 2013;1:44-51. 